\title{
Biblioteca naturii: realitate și metaforă în clasificarea botanică
}

\author{
Ioan Milică \\ Facultatea de Litere, Universitatea „Alexandru Ioan Cuza”, Bd. Carol I 11, 700506 Iaşi, România \\ Biblioteca Centrală Universitară „,Mihai Eminescu”, Str. Păcurari 4, 700511 Iași, România
}

\section{Despre articol}

Istoric:

Primit 29 aprilie 2020

Acceptat 15 mai 2020

Publicat 10 iunie 2020

Cuvinte-cheie:

bibliotecă

metaforă

taxonomie botanică

nomenclatură binomială

lingvistica textului

\begin{abstract}
Rezumat
Rețeaua de metafore care învăluie cunoașterea științifică suscită astăzi interesul multor cercetători. O literatură de specialitate tot mai consistentă semnalează că gîndirea şi exprimarea metaforică aduc științei atît beneficii cît şi deservicii, astfel că obiectul principal al lucrării de faţă este de a sonda relevanța unor metafore generate de scris și potențate de prestigiul acestei tehnologii comunicative. Corelațiile și ramificările acestor matrice pot fi, la rigoare, cartografiate prin lectura textelor de referință. Interpretate ca noduri de rețea, operele fondatoare în știință au forța de a schimba traiectoria explorării științifice și a reconfigura felul în care înțelegem să ne raportăm la realitate. Întrucît asumarea sarcinii de a sonda arhitectura metaforică a tuturor textelor știinţifice de prim rang ar depăşi cu mult mizele particulare ale lucrării de față, am preferat să reliefăm cîteva din matricele metaforice centrale ale tradiţiei scrisului pe care le regăsim în opera lui Carl von Linné, cu observația că, în posteritate, modelul clasic de categorizare impus în științele naturale de învățatul suedez a consolidat stabilitatea vocabularelor botanice vernaculare și a favorizat popularizarea și internaționalizarea multor denumiri științifice de plante. Axul în jurul căruia este organizată argumentarea este reprezentat de metafora bibliotecii.
\end{abstract}

„Nomina si nescit perit et cognitio rerum”
Carolus Linnæus, Philosophia botanica, 1751

\section{Preliminarii}

Pe măsură ce scrisul s-a afirmat ca cel mai potrivit mijloc de tezaurizare a cunoașterii, aspectele și activitățile relevante presupuse de acesta-alfabete, instrumente de scris, tipuri de texte, actul sau tehnica de a scrie, precum și activitatea de a citi-au dobîndit valorificări și semnificații multiple, menite să consolideze autoritatea respectivei tehnologii comunicative. Considerată din unghi semiotic, fiecare din etapele importante în evoluția scrisului-scrisul de mînă, scrisul de tipar, scrisul electronic-pune în lumină existența unor rețele metaforice care străbat aidoma unor cursuri de apă peisajul istoric al cunoașterii. Această pînză diafană, dar rezistentă de analogii și conexiuni servește celor mai variate funcții particulare (cognitivă, argumentativă, ilustrativă, explicativă, expresivă etc.) aflate sub umbrela funcției de comunicare a limbajului uman (Gafton \& Gafton, 2015).

Rețeaua metaforelor scrisului are caracter organic, în interpretarea filosofică propusă de Cassirer (2008, p. 109-111): principiu speculativ universal, unitate care există în totalitatea individualităților. În timp, unele dintre elementele constitutive ale întregului au germinat în constelații autonome în raport cu matricea de origine. Ilustrări tipice pentru desfășurarea acestui proces de evoluție prin selecție culturală sînt arhitecturi primare precum ALFABET, LIMBĂ sau CARTE, cu numeroase concretizări în religie, artă și știință.

\footnotetext{
*Adresă de corespondență: ioanister@gmail.com.
} 


\section{Metafora cărții}

Ca artefact cultural de importanță cardinală în perpetuarea tradițiilor istorice ale scrisului, cartea constituie nucleul unor reflectări metaforice străvechi. Din moștenirea antichității greco-latine, creștinismul a preluat o însemnată zestre intelectuală pe care a îmbogățit-o cu un remarcabil cult al cărții și al interpretării. Deși nu există temei pentru a crede că asemănarea lumii naturale cu o carte ar avea rădăcini exclusiv creștine, știm că ideea străbate literatura creștină timpurie. Mai precis, după cum observă Crease (2006, p. 16), în creștinism „s-a încetățenit de secole ideea că lumea este înfățișată în două cărți fundamentale. Prima dintre acestea, natura (subl. n.), e o lume de semne care își dezvăluie sensurile atunci cînd e interpretată în acord cu scriptura (subl. n.), cea de-a doua carte, din care aflăm înțelesul suprem sau gramatica semnelor naturii. Cele două cărți se citesc nedespărțite, trecînd de la una la cealaltă, de la ceea ce există în natură la ceea ce se zice în scriptură”. Altfel spus, în viziune creștină, „cele două cărți ne-au fost date de același Dumnezeu; pe cea dintîi am primit-o prin facerea lumii, cea de-a doua a fost scrisă mai apoi. Cunoașterea pe care o avem despre cartea naturii precedă și confirmă Scriptura, fiind ca o poartă deschisă către Biblie și ca o iluminare a cuvintelor acesteia" (Tanzella-Nitti, 2005, p. 241). Mai mult decît atît, în viziunea unor autori creștini prerenascentiști, liber nature și liber scripture coexistă fără contradicții, astfel că tot ceea ce se află în prima carte, se regăsește și în cea de-a doua. Natura dezvăluie alfabetul sacru al creației, Scriptura subliniază voința și puterea universal creatoare a autorului divin. Citind în armonie cele două cărți, omul înțelege că el însuși reprezintă cel mai important cuvînt din marea carte a Creației (Tanzella-Nitti, 2005, p. 241).

În Renaștere, consemnarea observaţiilor empirice și experimentelor care au permis formularea unor legi ale naturii a deschis o nouă perspectivă asupra legăturii dintre cartea naturii și cartea scripturii. Fără a sfida ideea că Dumnezeu atotputernicul este arhitectul și ziditorul lumii, învăţaţi precum Galileo Galilei sau Johannes Kepler au arătat că, pentru a desluși tainele universului, omul trebuie mai întîi să deprindă limba tehnică ${ }^{1}$ în care a fost scrisă marea carte a lumii. În contrast cu tradiţia timpurie, conform căreia oricine poate citi semnele din cartea naturii (Sf. Augustin), scrierile unor cărturari din epoca Renașterii prevestesc opoziția instituită ulterior între liber nature și liber scripture. Mai exact, opera divină devoalează existența unui conflict între limbajele și cititorii cărților creației (Tanzella-Nitti, 2005, p. 243) și, după cum arată Crease (2006, p. 16), această tensiune devoalează o ruptură în interpretarea condiției celor două cărţi simbolice: „Pentru a înțelege natura nu mai era nevoie ca cineva să recurgă la ajutorul alegoric al Bibliei, astfel că observarea naturii a fost concepută ca activitate independentă, desfăşurată de o categorie distinctă de învățați. Prin urmare, cartea naturii a fost considerată ca text primar sau ca prototip scris în limbaj tehnic, pe cînd scriptura a fost privită ca manual pe înțelesul tuturor, scris în limbaj popular”.

În rezonanță cu această perspectivă, în secolul al XVII-lea se instaurează și o schimbare în regimul de lectură al celor două cărți. Din unghiul limbajului tehnic în care este scrisă, cartea naturii presupune o descifrare mai cu seamă rațională, întemeiată pe observație. În lumina mesajului transmis, scriptura are un înțeles inspirat de divinitate. Între cunoașterea bazată pe demonstrație și credința întemeiată pe revelație se instaurează o opoziție dialectică. Pe teren cultural, acest proces de raționalizare a cunoașterii semnalează o schimbare de paradigmă și de accent în economia valențelor atribuite observației, pe de o parte, și interpretării, pe de altă parte. Pe măsură ce cununa de lauri trece de pe fruntea teologului ori a literatului pe cea a geometrului ori a naturalistului, străvechiul echilibru dintre liber nature și liber scripture va fi conceput și înfățișat metaforic în termenii unei inegalităţi: expansiunea unui univers raţional, ordonat, inteligibil implică o dislocare a lumii în care domină revelația, credința și interpretarea alegorică a scripturii. În epoca Luminilor, asimetria dintre explicit și implicit, dintre denotație și conotație, dintre noțiune și imagine va conduce către o și mai netă profilare a specificului gîndirii științifice în raport cu religia sau cu artele.

\footnotetext{
${ }^{1}$ Pentru Galilei, limba care luminează accesul prin labirintul altfel întunecat al universului nu este alta decît matematica (cf. Tanzella-Nitti, 2005, p. 243). În viziunea lui Kepler, astronomii sînt preoți ai Prea Înaltului Dumnezeu din cartea naturii (Harrison, 2004, p. 59-84).
} 


\section{Metafora bibliotecii}

Reflectările metaforice ale cărții au favorizat germinarea și înflorirea unei alte matrice, avînd ca nucleu noțiunea de BIBLIOTECĂ. În mentalitatea medievală, cartea și biblioteca au constituit surse excelente de simbolizare a memoriei. În acest sens, se cuvine să remarcăm că desemnarea memorării şi memoriei prin recurs la diverse metafore ale scrisului consolidase, încă din antichitate, ideea că „memoria e în mare parte ca o carte, ca o pagină scrisă sau ca o tăbliță de ceară pe care scrie ceva” (Carruthers, 2008, p. 18). Acestui prim model de conceptualizare a memoriei, tabula memorie, is-a asociat un al doilea, thesaurus sapientie, valorificat pentru a face referire la organizarea internă a memoriei. Mai precis, conceperea memoriei ca „bibliotecă de texte puse la dispoziție și utilizate prin aplicarea conștientă a unor scheme euristice” (Carruthers, 2008, p. 39), a avut rolul de a sublinia caracterul organizat al unei memorii bine educate. După cum cărțile dintr-o bibliotecă sînt ordonate în acord cu un sistem de clasificare rațional și exhaustiv, tot astfel educarea riguroasă și continuă a memoriei determină constituirea unui tezaur de înțelepciune. Cultivarea sistematică a memorării contribuie direct și activ la dezvoltarea bibliotecii memoriei. În conștiința multor cărturari medievali, în inima acestei biblioteci imaginare se află Biblia, carte a cărților, simbol suprem al armoniei universale (Rieger, 2000).

Conexiunile stabilite între concepte precum CARTE şi BIBLIOTECĂ, pe de o parte, și MEMORIE, respectiv NATURĂ, pe de altă parte, evidențiază nu numai faptul că de la o epocă la alta se produc reconfigurări simbolice care, în fond, indică dimensiunea istorică a culturii, ci și că această variație ar putea fi, la rigoare, reconstituită și cartografiată, în raport cu diverse arii și domenii ale cunoașterii umane. În lucrarea de față, prin raportare la modelul de clasificare științifică propus de Carl von Linné, voi sonda tripla configurare metaforică a ideii de bibliotecă: 1. spațiu privilegiat al observaţiei și cunoașterii, 2. tezaur (enciclopedic) de cunoștințe, 3. sistem de organizare a informației. Fără a exclude amănuntul că aceste valențe nu pot reface în chip complet ipostazele simbolice ale bibliotecii în cunoașterea și comunicarea de tip erudit, este important să distingem filoanele principale, astfel încît, mai apoi, să le putem explora ramificările.

\subsection{Taxonomie şi nomenclatură}

În istoria științelor naturale, Carl von Linné, reformator al clasificării sistematice și al denumirilor erudite, este autorul unor lucrări de pionierat. Contribuțiile sale la dezvoltarea biologiei, în general, și a botanicii, în particular, sînt numeroase și fac obiectul unei bibliografii ample. Dezbaterea privind tradiția intelectuală și sursele livrești ale viziunii lui Linné asupra lumii naturale este interesantă atît din unghi biologic, cît și filologic (Heller, 1983; Stearn, 1959), iar influența școlii sale asupra cursului științei în secolul al XIX-lea (Stafleu, 1971) este tot atît de evidentă ca și izvorul aristotelic (Archibald, 2004; Cain, 1958) al modelului de categorizare oglindit de taxonomia şi nomenclatura linneană.

Portretul cărturarului este schițat de Stearn (în Blunt, 2001, p. 6), care subliniază trăsăturile de personalitate puse în valoare de operă: „cunoștințe vaste, dar nu neapărat profunde, exprimare clară și concisă, sîrguință și tenacitate remarcabile, darul de a sistematiza și de a corela faptele, avînd conștiința importanței acestora în epocă”. Să adăugăm că lucrările învăţatului suedez poartă însemnele Iluminismului și ale tendinţelor filosofice dominante în secolul al XVIII-lea: raționalism, empirism și credința în marele lanț al fințtei (Serafini, 1993, p. 142). Admirator al culturii clasice, Linné a valorificat literatura și mitologia greco-latină pentru a boteza peste patru mii de specii de animale și aproape opt mii de specii de plante (Stearn, în Blunt, 2001, p. 246).

Părintele botanicii moderne a fost în permanență preocupat să afle calea cea mai potrivită pentru a clasifica și denumi realitățile lumii vii. În concepția sa, filosofia naturală, adică studiul sistematic al naturii, se sprijină, după cum se constată atunci cînd avem în atenție lumea plantelor, pe doi piloni: taxonomia și nomenclatura. În sinteza ${ }^{2}$ sugestiv intitulată Philosophia Botanica (Știința botanicii, 1751), Linné afirmă că cele două fundamente ale botanicii, clasificarea plantelor și denumirea acestora, au funcții distincte.

\footnotetext{
${ }^{2}$ Concepută ca un calendar, lucrarea e organizată în 12 capitole, simbolizînd lunile anului, și cuprinde tot atîtea observații și recomandări științifice (aforisme) cîte zile numără un an obișnuit.
} 
În timp ce clasificarea are rolul de a reliefa asemănările și deosebirile dintre plante și de a stabili, astfel, o metodă de sistematizare, denumirea servește scopului de a desemna și de a caracteriza plantele, adică de a indica poziția ocupată de fiecare specimen în sistemul de descriere structurală evidențiat prin operația de clasificare. Adăugînd că diviziunile taxonomice stabilite de Linné (clasă, ordin, gen, specie, varietate) sint determinate prin descrierea structurală, opozitivă, a caracteristicilor plantelor, rezultă că denumirile binare, alcătuite în acord cu formula [nume de gen (generic) + nume de specie (specific)], sînt coordonate ale unui sistem indicial, așa cum latitudinea și longitudinea marchează un punct oarecare de pe suprafața terestră. Aidoma altor unități de măsură, nomenclatura binomială este simbolizarea semiotică esențială a unei descrieri structurale analitice. Prin urmare, taxonomia și nomenclatura stabilite de cărturarul suedez dezvăluie un complex proces de transfer. Mai întîi, naturalistul observă realitatea, apoi realizează descrierea concisă și sistematică a specimenului căruia îi determină identitatea, după care sublimează descrierea analitică într-o denumire cultă alcătuită dintr-un nume generic şi unul specific, semnalînd prin axele indiciale ale denumirii integrarea specimenului în sistemul de clasificare. Așadar, întregul mecanism procedural are temei empiric, întrucît naturalistul cercetează realitatea și o descrie în conformitate cu ceea ce observă, are bază rațională, dat fiind că identitatea oricărui element natural este stabilită urmînd tradiția logicii aristotelice ${ }^{3}$, prin distingerea elementelor specifice de cele comune cu alte realități similare, și are caracter inclusiv (enciclopedic), deoarece permite adăugarea de noi elemente în măsura în care acestea sînt integrate în sistem în conformitate cu aceleași standarde de clasificare.

În consecință, clasele stabilite de Linné reflectă ceea ce Rosch (1999) consideră a fi perspectiva tradițională asupra categorizării. În acord cu această viziune, pe care Iluminismul a valorificat-o critic, 1. orice categorie, definită ca produs al procesului mental de clasificare a obiectelor, trebuie să fie exactă, adică să fie precis delimitată, 2. orice categorie implică existența unor trăsături necesare şi suficiente pentru a include cît mai mulți membri și 3. toți membrii unei categorii trebuie să fie deopotrivă de reprezentativi. $\mathrm{Cu}$ alte cuvinte, taxonomia și nomenclatura stabilite de părintele botanicii moderne reflectă un sistem de clasificare 1) precis, dat fiind că includerea unei componente într-o categorie se face fără ambiguități, 2) exhaustiv, deoarece sistemul permite clasificarea tuturor componentelor realității şi 3) echipolent, întrucît toți membrii unei categorii au acelaşi statut valoric. După cum voi încerca să arăt în secțiunile următoare, sistemul linnean de clasificare s-a dovedit și un potent vehicul metaforic.

\subsection{Biblioteca și labirintul}

Într-o suită de studii excelente dedicate operei lui Linné, filologul american John Lewis Heller (19061988) probează că stilul lapidar și esențialist al savantului suedez urmează, fără dubiu, o traiectorie retorică de factură clasică, fiind, de altfel, infuzat cu citate, referințe și aluzii din literatura greco-latină (Heller, 1983, passim). Conștient că, pentru a se impune, noua metodă naturală necesita virtuți compoziționale pe măsură, Linné nu abandonează tradiția, ci o înglobează în viziunea sa (Stearn, 1959). Preluînd de la înaintași elementele valoroase, demne de reținut, naturalistul supranumit princeps botanicorum (prințul botaniștilor) a fructificat rețete expresive menite să consolideze și să ornamenteze edificiul demonstrațiilor sale ştiințifice, astfel că stilul linnean s-a impus ca reper şi ca standard de expunere savantă. Relevantă în acest sens este înfățișarea lumii naturale prin prisma ideatică și stilistică a două matrice cu o bogată ilustrare metaforică în scrierile erudite: BIBLIOTECA și LABIRINTUL ${ }^{4}$.

\footnotetext{
${ }^{3}$ Una dintre cele mai influente viziuni privind realizarea operațiilor de clasificare este concepția lui Aristotel, pentru care „categoria semnifică, totodată, un aspect al limbajului (inclusiv al gîndirii vorbite, exprimate) şi un aspect al existenței” (cf. Florian, 1997, p. 76). Pentru Aristotel, dubla identitate—cognitivă şi lingvistică—a categoriilor se sprijină pe solidaritatea dintre gîndire şi limbaj şi trebuie pusă în relație cu planul componentelor lumii. Orice lucru, afirmă Aristotel, este, în sine, o unitate, iar omul are capacitatea de a identifica şi de a exprima atributele lucrurilor. Categoriile identificate şi discutate de Aristotel sînt prezentate conform unei clasificări de tip binar (absența sau prezența unui atribut configurează o anumită identitate categorială), iar acest model clasic a fost valorificat și de Linné (cf. Cain, 1958).

${ }^{4}$ În accepția din studiile culturale, labirintul este „o schemă antropologică, poliedrică, interdisciplinară și atotcuprinzătoare, capabilă să ilumineze spații vaste ale imaginarului colectiv, pentru că vorbește despre condiția umană și / sau cosmică” (Bădeliță, 2019, p. 12).
} 
În strînsă legătură cu străvechea conceptualizare a memoriei ca bibliotecă, spiritul enciclopedic al Iluminismului aduce în prim-plan o metaforă de carieră: bibliotheca nature. În opera lui Linné, această matrice dobîndește o interpretare originală, după cum se va vedea în cele ce urmează.

În primul rînd, se cuvine evidențiat șirul de bibliografii publicate sub titlul Bibliotheca Botanica. Contemporani cu Linné, autori precum savantul elvețian Albrecht von Haller (1708-1777) sau naturalistul francez Jean-François Séguier (1703-1784) au aspirat să adune în cataloage de referință tot capitalul intelectual al contribuțiilor dedicate lumii plantelor încă din cele mai vechi timpuri. Astfel de lucrări cu ambiții exhaustive și cu vădit caracter metatextual organizau un inventar impresionant de informații referitoare la diverse surse livrești: ierbare, farmacopei, dicționare, scrieri de călătorie, cataloage de bibliotecă etc. și dezvăluiau că spiritul enciclopedic al epocii miza „pe date derivate din experiența științifică și pe o critică a falselor opinii din trecut” (Eco, 2016, p. 337). Implicit, această manieră de a privi realitatea prin ochean bibliografic devoalează un mecanism elementar al cunoașterii savante, și anume necesitatea de a ști ce cunoștințe s-au acumulat deja într-un anumit domeniu şi despre un anumit subiect. Totuşi, rețeaua care învăluie o anumită realitate într-o țesătură invizibilă de referințe bibliografice necesită sistematizare și sedimentare critică, astfel că, în absența călăuzelor de încredere, investigarea acestui labirint al cărților se dovedește, ca și explorarea propriu-zisă a labirintului naturii, o întreprindere anevoioasă și riscantă. De aceea, sistematizarea resurselor documentare și citarea facilă a acestora sînt, în concepția lui Linné, cheile de aur care deschid poarta științei. Fără acces rapid și eficient la această rețea de referințe bibliografice care asigură, ca un sol fertil, înflorirea gîndirii științifice, cunoașterea savantă nu poate aspira să parcurgă cu succes labirintul complex al realității.

În al doilea rînd, nu se poate neglija detaliul că modelul linnean de clasificare științifică a fost mai întîi testat în realizarea unei sistematizări bibliografice cu dublă funcție, indicativă și mnemonică. Mai precis, învăţatul suedez considera că pentru descrierea corectă a realului, orice naturalist trebuie să stăpînească, în egală măsură, trei arhitecturi de sistem: sistemul referințelor și mențiunilor bibliografice, sistemul taxonomic și nomenclatura binomială. Din această credință derivă, după cum relevă William T. Stearn (19112001), atenția acordată formulei binare de menționare bibliografică ${ }^{5}$. Mai simplu spus, către mijlocul secolului al XVIII-lea, o memorie educată—precum cea a lui Linné-putea reproduce fără greș citate, referințe și aluzii livrești, precum și toate diviziunile lumii naturale, dimpreună cu numele savante ale ființelor și lucrurilor astfel denumite. Ca și natura, mintea omului de știință este o bibliotecă vie.

$\mathrm{Nu}$ în ultimul rînd, lectura atentă a scrierilor lui Linné, îndeosebi a celor care stabilesc concordanțe între clasificarea bibliografică a lucrărilor de botanică și taxonomia plantelor, precum Bibliotheca Botanica (1735) sau Philosophia Botanica (1751), le-a permis specialiștilor să reconstituie mizele multiple (științifice, didactice, retorice) ale publicării respectivelor contribuții. Am căpătat astfel acces în laboratorul de idei al unui savant care a influențat decisiv evoluția științei și nu este greșit să presupunem că natura și cărțile au fost marile pasiuni ale lui Carl von Linné. De fapt, dacă luăm aminte la tehnica de realizare a catalogului intitulat Bibliotheca Botanica (1735), nu ne îndepărtăm de adevăr atunci cînd presupunem că matricea metaforică a bibliotecii, înțeleasă atît ca 'tezaur de cunoștințe', cît și ca 'sistem de clasificare', pune bine în valoare noutatea și polivalența clasificării sistematice. În acord cu prezentarea amănunțită realizată de Heller (1983, p. 146-202), stilul alegoric din prefața catalogului reflectă nu numai puterea creatoare a imaginației lui Linné (Heller, 1983, p. 146), ci și obiectivul didactic al clasificării autorilor în acord cu „metoda naturală, astfel încît studenţii să știe ce cărți ar trebui să aleagă și cum să recunoască autorii care au scris despre un aspect sau altul al științei noastre” (Linné, apud Heller, 1983, p. 155).

Grație acestei abordări sistematice, instrumentul de lucru creat de maestru în beneficiul discipolilor este, spre a invoca o metaforă linneană de mare forță plastică și persuasivă, firul salvator al Ariadnei care

\footnotetext{
${ }^{5}$ Întrucît denumirile științifice ale plantelor se alcătuiesc conform binomului nume generic (nume de gen) - nume specific (nume de specie), același mecanism se poate utiliza și în citarea izvoarelor bibliografice: „La fiecare citare, numele autorului trebuie redat în formă prescurtată, în corelație cu numele generic al unei plante, ca și opera menționată, în corelație cu numele specific; dat fiind că prestigiul unui anumit autor nu se datorează exclusiv unei lucrări, ci mai multora, titlul unei cărți se restrînge la un singur cuvînt" (Linné, Critica botanica, 1737, p. 322, apud Stearn, 1959, p. 5).
} 
Ioan Milică

indică drumul prin labirintul bibliotecii botanice. Într-o altă lucrare, Philosophia Botanica (2005 [1751]), firul Ariadnei este reprezentat de sistemul de clasificare a plantelor, fără de care botanica ar fi un haos. Paralela cărți - plante \|l clasificare bibliografică - taxonomie botanică îndreptățește constatarea că înțelesul primar atribuit noțiunii de sistem este cel de 'cadru cuprinzător de elemente constitutive' (Heller, 1983, p. 147). Prefigurarea naturii ca bibliotecă sistematic organizată are scopul de a legitima metoda de clasificare stabilită de Linné. Titlurile în limba latină ale lucrărilor incluse în catalog au statutul taxonomic al speciilor și varietăților de plante. Numele autorilor au rangul taxonomic de gen (Heller, 1983, p. 152). În acord cu diviziunile superioare ale ierarhiei, gruparea autorilor și a lucrărilor se realizează în ordine și clase (cf. Anexa A). Biblioteca din mintea unui savant este organizată după principiile categorizării aristotelice și, din acest unghi, nu este lipsit de importanță să remarcăm că cele 833 de volume clasificate sistematic de Linné indică natura selectivă a catalogului (Heller, 1983, p. 159).

Pe de o parte, selecția reliefează preocupările bibliografului, pe de altă parte, catalogul îi oferă maestrului oportunitatea de a-i îndemna pe studenți să deprindă taxonomia și nomenclatura noii metode naturale încă din etapa timpurie a studiului în bibliotecă. În timp, actualizarea și prelucrarea informațiilor bibliografice cuprinse în catalogul tipărit mai întîi în 1735 a favorizat realizarea unor sinteze precum Philosophia Botanica. Nu întîmplător, acest volum de maturitate științifică are un prim capitol intitulat Bibliotheca, în care autorul esențializează clasificarea sistematică a referințelor bibliografice și o rafinează cu semnalări discrete privind importanța acestora în istoria botanicii, notînd cu majuscule numele celor mai importanți autori, de altfel foarte puțini la număr: Konrad Gesner (GESNERUs 1541), Andrea Cesalpino (CÆSAlpinus 1583), Gaspard Bauhin (BAuhinus 1593), Robert Morison (MORISON 1669), Joseph Pitton de Tournefort (TOURnefort 1694) și Sébastien Vaillant (vaIllant 1717). Această ierarhizare depășește miza elementară a stabilirii unei diviziuni între lucrările de importanță principală și cele de importanță secundară și semnalează, prin numele-cheie, care sînt, de fapt, reperele clasificării bibliografice. Scara valorică a contribuțiilor la dezvoltarea botanicii configurează nu atît o bibliotecă organizată în spirit didactic, cît o bibliotecă ideală (Heller, 1983, p. 165), o constelație a minților strălucite. Aidoma firului Ariadnei, lumina științei trasează drumul prin labirintul realității.

\section{Scara lui Aristotel}

Pentru cititorul contemporan, clasificarea bibliografică linneană „constituie un izvor de mari neplăceri” (Heller, 1983, p. 200 ș.u.). Deprinderea savantului suedez de a reda în limba latină titlurile tuturor lucrărilor catalogate, indiferent dacă acestea au fost sau nu redactate în limba științei de pînă în secolul al XVIIIlea, nesiguranța unora dintre informațiile bibliografice furnizate (an de apariție, ediție), precum și decizia evident arbitrară de a ordona contribuțiile după un pretins scop urmărit de acestea subminează utilitatea practică actuală a catalogului bibliografic. În ciuda lipsei de acuratețe, experimentul atrage atenția asupra impactului major pe care l-a avut asupra pionierilor științei modelul de categorizare cunoscut drept SCARA LUi ARistotel. Ca și alte matrice metaforice ale scrisului-Alfabetul, CARTEA, BiblioteCA etc.scara aristotelică are un dublu orizont, sacru și profan, constituind nucleul unui arhetip simbolic, MARELE LANȚ AL FIINȚEI (Lovejoy, 2001). Pe scurt, după cum constată Archibald (2004, p. 1-7), clasificarea realităților naturii în conformitate cu apartenența lor la diverse genuri și specii a creditat totodată și o ierarhizare bazată pe existența unui continuum între categorii. Pe treapta cea mai de jos a scării se află lucrurile simple, lipsite de viață, pe treptele tot mai înalte stau organismele de complexitate crescîndă (plante, animale, oameni). În Evul Mediu, scara lumii (scala nature) s-a îmbogățit și cu orînduirea ființelor cerești (scala cali), întregindu-se, astfel, marele lanț al creației. De altfel, în tradiția creștină cultă şi populară rețeaua simbolică a scării este cu adevărat impresionantă. Revigorarea post-renascentistă a viziunii aristotelice a culminat, în secolul al XVIII-lea, cu întocmirea unor diagrame detaliate ale lumii vii (cf. Archibald, 2004, p. 7-11), iar naturaliști precum Carl von Linné au conservat imaginea unei naturi armonios alcătuite de voința și lucrarea divină.

După cum afirmă William T. Stearn, idealul savantului suedez a fost de a clasifica și denumi toate 
realitățile naturale cunoscute ale vremii sale: „prin 1753 Linné credea că numărul speciilor de plante din întreaga lume cu greu ar putea depăși pragul de 10.000, și, de-a lungul carierei sale, el a denumit în jur de 7.700 de specii de plante cu flori. Dar viața nu e chiar atît de simplă. Conform estimărilor moderne, doar numărul speciilor de plante cu flori se situează între 250.000 și 380.000, adică de cîteva ori mai mult decît a crezut Linné despre întregul regn vegetal, și genuri precum Senecio și Solanum înregistrează, fiecare, peste 1.000 de specii. De altfel, între 1900 și 1955, botaniștii au descris cu vădit optimism aproximativ 198.000 de specii noi de plante cu flori! Numărul curent al speciilor de Insecta se ridică la aproape 754.000 850.000 de specii, iar regnul animal însumează un total de 930.000 - 1.120.000 de specii. Pentru biologie a fost într-adevăr un noroc că Linné și-a trăit viața fără a avea cunoștință despre astfel de date statistice înfricoşătoare" (Stearn, 1959, p. 8-9).

Studiile asupra taxonomiei și nomenclaturii stabilite de naturalistul suedez au surprins cu exactitate faptul că prototipul aristotelic al clasificării sistematice l-a călăuzit pe părintele botanicii moderne către ideea de a simplifica descrierea polinomială clasică, echivalînd-o cu o formulă binară alcătuită dintr-un indicator nominal al genului (nume generic) și un indicator nominal al speciei (nume specific), astfel încît solidaritatea celor două elemente-cheie să redea esența observațiilor acumulate în descrierea analitică: „luate împreună, genus și differentia alcătuiesc definiția speciei, un argument al esenței acesteia” (Cain, 1958, p. 145). Cu alte cuvinte, denumirea constituie un indicativ de clasificare sistematică, asemenea plăcuțelor de înmatriculare ale autovehiculelor. Cu această înțelegere citim pasajele din Philosophia Botanica în care Linné lămurește statutul denumirilor de plante ${ }^{6}:$ "În descrierea verbală a plantelor, toate numele sînt fie mute (implicite - n.r.), precum cele privind clasa (160) și ordinul (161), fie sonore (explicite - n.r.) precum cele privind genul (159), specia (157) și varietatea (158)” (Linnæus, 2005, p. 170). Așadar, pentru orice botanist, denumirea științifică indică ce coordonate i se rezervă unei plante în tabloul lumii vegetale.

Dacă luăm ca exemplu denumirea savantă a florii soarelui, Helianthus annuus L., scara aristotelică a acestui nume științific are, în acord cu tradiția linneană ${ }^{7}$, următoarea dezlegare (Fig.1): numele exprimat indicăgenul (Helianthus < gr. helios 'soare' + gr. anthos 'floare') și specia (annuus 'anual'), în timp ce numele neexprimate (mute) indică: familia (Asteracee < gr. aster 'stea' + suf. -acee, specific rangului de familie), ordinul (Asterales < gr. aster'stea' + suf. - ales, specific rangului de ordin), clasa (Magnoliopsida < Magnolio 'Pierre Magnol (1638-1715), botanist francez care a introdus noțiunea de familie în clasificarea știinţifică a plantelor' + suf. gr. -(o)psida, specific rangului de clasă), diviziunea (Magnoliophyta < Magnolio + gr. phyta 'plante') și regnul (Plante).

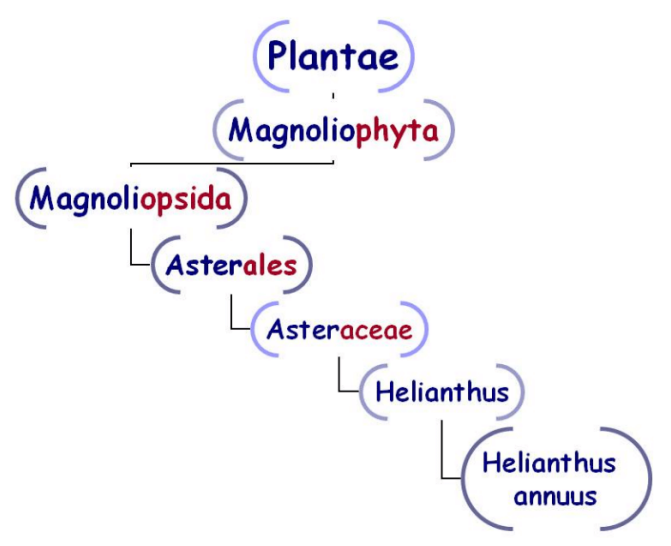

Figura 1: Scara aristotelică a denumirilor botanice: floarea-soarelui

După modelul onomastic al antroponimelor, Linné a stabilit că între elementele constitutive ale formulei binare se instituie o deosebire importantă: numele specific nu poate exista independent de numele generic

\footnotetext{
${ }^{6}$ Numerele trecute între parantezele rotunde indică aforismele din Philosophia botanica în care se definesc diviziunile clasificării sistematice stabilite de Linné.

${ }^{7}$ În botanica sistematică actuală sînt recunoscute șapte ranguri principale: regn, diviziune, clasă, ordin, familie, gen, specie.
} 
tot astfel cum prenumele nu se poate despărți de numele de familie în documentația oficială. Afirmînd că numele botanic legitim (Linnæus, 2005, p. 219, aforismul 257) presupune raportarea numelui specific la cel generic, părintele botanicii moderne a considerat genul, nu specia, ca unitate de bază a clasificării sale (Stearn, 1959, p. 9) și a acordat libertate deplină în alegerea numelor ${ }^{8}$, atîta vreme cît selecția lor „se realizează atent, onest și judicios” (Linnæus, 2005, p. 219, aforismul 256). În acest caz, paralela nume generic \| nume de familie - nume specific \|n nume de botez scoate în evidență dubla funcție a denumirilor științifice de plante: funcția de desemnare și funcția de identificare (Stearn, 1959, p. 13).

Funcția designativă are, în principal, finalitate mnemonică (ușurează memorarea genurilor), în timp ce funcției de identificare îi revine sarcina de a distinge și de a caracteriza speciile unui gen (Stearn, 1959, p. 8). Dacă ar fi să interpretăm nomenclatura binomială prin apel la categorii onomastice antroponimice, s-ar putea afirma că numele generic este asemănător numelui, în timp ce numele specific se aseamănă cu supranumele de tipul poreclelor. Cele două componente ale denumirilor botanice au constituire normată și, prin aceasta, caracter convențional explicit. Intenția lui Linné de a formula definiri binare raționale, esențiale și memorabile în raport cu descrierile structurale ale realităților naturale a presupus crearea de metafore deliberate?

\section{Metaforele nasc metafore}

Cercetarea aprofundată a taxonomiei și nomenclaturii stabilite de Linné a evidenţiat atît istoricul reformelor inițiate de savantul suedez (Stafleu, 1971; Stearn, 1959), cît și sursele ideilor sale (Cain, 1958; Heller, 1983). Pe terenul culturii române, influența exercitată de opera Carl von Linné asupra dezvoltării științelor naturale în a doua jumătate a secolului al XVIII-lea și în prima jumătate a secolului al XIX-lea a fost evidențiată în cîteva contribuții asupra primelor excursii și scrieri botanice (Brîndză, 1880; Bogdan, 1919; Borza, 1910, 1921, 1929). Totodată, au fost analizate și primele încercări de standardizare a lexicului științific românesc (a se vedea, de pildă, Coteanu, 1942; Aldea, 2011; Chivu, 2013, 2014; Soare, 2010). Persistă, totuşi, o serie de neclarități care subminează acuratețea cercetărilor interesate de observarea corelațiilor dintre elementele populare, reflectînd autoritatea tradiției orale, și cele culte, impuse de prestigiul scrisului. Încă din a doua jumătate a secolului al XIX-lea, unii dintre exploratorii folclorului autohton au denunțat influența nefastă a științei asupra limbii și creațiilor populare. De pildă, avocatul Simeon Mangiuca (1831-1890), semnala, într-un eseu închinat folclorului plantelor, că publicațiile românești de botanică ale timpului, între care și Catalogul plantelor grădinei botanice a școalei de medicină din București (1866), ,sînt foarte manche și defectuoase, căci autorii acestor colecțiuni, tratate și opuri nu au descălecat la poporul nostru românesc spre a-l consulta despre botanica română, ci mai vîrtos s-au mărginit a traduce pe română numirile plantelor din limba greacă, romană și germană ori simplu a primi denumirile din aceste limbi (subl. n.)” (Mangiuca, 1874, p. 512). Fără a trece cu vederea meritele unei astfel de pledoarii în favoarea adunării folclorului, e limpede că literatul transilvănean nu a avut în atenție contribuțiile importante ale unor farmaciști și medici precum J. Benkö, I. C. G. Baumgarten, I. Czihak, J. Szabo și alții (cf. Brîndză, 1879-1883), realizate în conformitate cu metoda linneană de clasificare sistematică a plantelor. Prin urmare, tabloul de ansamblu creionat în presa culturală era, în parte, deformat de lipsa de acces la informația științifică de calitate.

În realitate, aşa cum arată dr. A. Fătu, fondatorul grădinii botanice din Iaşi, trecerea în revistă a rezultatelor științifice înregistrate pînă la mijlocul veacului al XIX-lea, semnala fără greș „cît de puțin interes am pus noi la dezvoltare părții științifice, de unde provine și neînsemnarea rezultatelor ce am dobîndit în acest ram al cunoștințelor” (Fĕtu, 1873, p. 13). Cu alte cuvinte, blamul pare mai degrabă un artificiu retoric, în condițiile în care, în perioada respectivă, numărul publicațiilor ştiințifice şi de popularizare a

\footnotetext{
${ }^{8}$ „Numele triviale pot fi probabil stabilite în acelaşi fel în care am procedat în Pan Suecicus și ar consta dintr-un singur cuvint, cuvînt ales liber din orice sursă” (Linnæus, 2005, p. 220, aforismul 257).

${ }^{9}$ Dezbaterea privind semiotica metaforelor deliberate poate fi urmărită pornind de la contribuții precum Steen (2011) și Gibbs (2011).
} 
științei și impactul instituțiilor ${ }^{10}$ care ar fi putut extinde influența științei asupra poporului dovedeau că „Sîntem cu totul modești” (Fětu, 1873, p. 18). Fapte precum nepublicarea unor lucrări de referință (Gh. Șincai, J. Szabo) sau neglijarea marelui ierbar ${ }^{11}$ alcătuit de farmacistul J. Szabo ca rezultat al excursiilor de documentare botanică întreprinse în Moldova după 1840 sînt mai elocvente în a ilustra lipsa de preocupare publică faţă de dezvoltarea științelor naturale decît prejudecata că știința macină folclorul. Totuși, observația că învăţații vremii au tradus din alte limbi denumirile de plante merită luată în considerare, deși nu în sensul exagerat polemic ${ }^{12}$ adoptat de Mangiuca.

Impulsul decisiv al Iluminismului asupra culturii românilor se face simțit către sfîrșitul secolului al XVIII-lea, după 1780, iar un semn de netăgăduit al acestei influențe constă, ca și în alte părți ale Europei, în manifestarea unui interes tot mai sporit față de traducerea textelor specializate, concomitent cu trecerea în plan secund a activității de traducere a textelor religioase (Jeanrenaud, 2014, p. 12). Cea mai recentă antologie a operelor publicate de cărturarii Școlii Ardelene probează că repertoriul traducerilor realizate în epocă este divers: istorie, literatură, morală și filosofie, pedagogie, economie, știință, drept, teologie etc. (Pavel, 2018). Constatînd că activitatea de traducere este consolidată, după 1830, prin publicarea primelor manuale de istorie naturală, nu ne rămîne decît să adăugăm că pînă la 1860 se înființează primele muzee și primele grădini botanice, la Iași și la București. În deplină rezonanță cu fondarea bibliotecilor academice și cu înființarea universităților, astfel de iniţiative cultural-științifice atestă dorința de a realiza, după modelul marilor centre intelectuale din Europa, instrumente și mijloace de lucru potrivite pentru nevoile de studiu și de cercetare ale primelor generații de studenți.

Dacă luăm ca reper cataloagele grădinilor botanice din București (Hofman, 1866) și din Iași (Fětu, 1871) descoperim în cuprinsul acestora practica aparent bizară de a traduce în limba română denumirile savante ale plantelor stabilite după „sistema lui Lineu” (Fětu, 1873, p. 76). Cît de curioase trebuie să le fi părut cititorilor nefamiliarizați cu tipicul codificărilor biologice ${ }^{13}$ denumiri precum Asfodel galben (Asphodelus luteus), Zambilă moțată (Muscari comosum Miller) sau Funkia albă (Funkia alba Sweet)! Și cît de exotice trebuie să fi fost considerate, la prima vedere, nume de plante calchiate precum Camelină cultivată (Camelina sativa), Isatidă plumbia (Isatis lævigata) sau Miagră străpunsă (Myagrum perfoliatum)!

Reacții publice precum cea exprimată de Simeon Mangiuca indică, pe de o parte, contactul fragil cu perspectiva savanților asupra bibliotecii naturii și, pe de altă parte, șocul provocat de dezvăluirea acestui labirint surprinzător. Scriind că artificiul traducerii nu face decît să complice lucrurile și să ridiculizeze sau să strice limba cea veche și curată a poporului, comentatorii de ocazie nu par să fi luat în considerare amănuntul deloc trivial că nu toate plantele din această lume erau cunoscute și denumite de români. Prin urmare, multe denumiri noi de plante au fost create prin calchiere, prin împrumut sau prin recurs la vocabularul deja existent de fitonime. Așadar, energiile de semnificare ale limbajului au fost valorificate pentru a crea un stil apt să exprime reflecția științifică, însă procesul de standardizare terminologică are implicații semiotice formidabile, dat fiind că limba este, ca și natura, un labirint: „în mijlocul acestui labirint de semnificațiuni ale aceleiași vorbe, fără un fir al Ariadnei, este cineva foarte expus a se confunda și rătăci” (Laurian \& Massim, 1871, p. xii). În labirintul înșelător al cuvintelor, metaforele nasc metafore

\footnotetext{
${ }^{10}$ „Așadar noi avem: mai multe asociațiuni științifice, două muzee, două grădini botanice, mai multe școli publice (peste 2.400 - n.r.), cari, între altele sînt menite să contribuie la și ele la propagarea științelor fizico-naturale (...), 15 gimnazii, 6 licee, 8 seminarii, 2 universități: cea din Iași cu trei facultăți: litere, științe și drept, acea din București, pe lîngă acestea și o facultate de medicină, de care depinde școala de farmacie și veterinară, 35 de școli private de ambe sexe, în care intră Institutul academic şi Liceul nou din Iași” (Fĕtu, 1873, p. 18).

${ }^{11}$ „Dr. I. Szabo, a făcut încă din anul 1842 mai multe excursiuni botanice în Moldova, la care ocaziune el a adunat un însemnat număr de plante, cu cari a format un ierbar ce conține 2844 de exemplare de diferite specii de plante, cari se conservă și astăzi în muzeul de științe naturale din Iași, paguba însă este că ierbarul în chestiune a rămas neclasificat” (Fĕtu, 1873, Anexa B, p. 75).

${ }^{12}$ „În astfel de procedură spre a batjocori botanica română mai vîrtos excelează sus citatul catalog al plantelor grădinii botanice din București din anul 1866 și acestea să fie zise spre rușinea României” (Mangiuca, 1874, p. 513).

${ }^{13}$ Exemple preluate din Hofman (1866, p. 4, 26).
} 
(Laurian \& Massim, 1871, p. xiii).

\section{Spirala traducerii}

Cu toate că, în secolul al XIX-lea, latina a cedat limbilor vernaculare locul de onoare în exprimarea cunoașterii savante, învățații nu au renunțat la tradiția de a valorifica bazele greco-latine ale limbajului științific pentru a crea cuvinte noi. Stabilitatea desemnării întreține viața terminologiilor culte, astfel că, în studiul științific al plantelor, „cuvintele tehnice introduse în ultimele două secole și jumătate au rămas în esență aceleași: 'petal' (petalum), 'anther' (anthera), 'polen' (pollen), 'carpel' (carpellum) și 'stigma' (stigma) în engleză, 'pétale, 'anthère, 'pollen', 'carpelle' și 'stigmate' în franceză, 'petalo, 'anthera,' 'polline', 'carpello' și 'stimma' în italiană, 'pétala' (port.), 'pétalo' (span.), 'antera,' 'polen', 'carpelo' și 'estigma' în portugheză și spaniolă, 'petale,' 'antere,' 'polen', 'carpelă și 'stigmat' în română’ (adaptare după Stearn, 2013, p. 44).

Istoria culturală a termenilor științifici are, de regulă, o țesătură complicată. Puţini dintre vorbitorii de rînd au conștiința că plante ornamentale precum begoniile (cf. Fĕtu, 1871, p. 20), gențianele (cf. Hofman, 1866, p. 20) sau primulele (cf. Hofman, 1866, p. 20) au dobîndit nume provenite din „traducerea” denumirilor savante de gen abia după ce plantele respective au fost cultivate în grădinile botanice întemeiate la noi în jurul anului 1860. În astfel de cazuri, primele dovezi ale acestui proces de naturalizare lingvistică pot fi descoperite în cataloagele care au stîrnit indignarea apărătorilor botanicii populare. De altfel, aceste surse bibliografice culte nu sînt doar excelente izvoare de nume popularizate prin calchiere parţială sau totală ori prin împrumut, ci şi materiale care au contribuit la consolidarea vocabularului botanic referitor la cele mai diverse aspecte din viața plantelor: înfățișare, habitat, întrebuințare etc.

La un secol de la impunerea sistemului linnean, adaptarea terminologiei botanice la specificul limbilor moderne a presupus o reconsiderare a normelor privind denumirea plantelor. În consecință, la Congresul Internaţional de Botanică organizat la Paris în 1867 au fost adoptate noi reguli de stabilire a nomenclaturii binomiale. La art. 6, pe lîngă cerința linneană de a atribui plantelor nume binare latinești, a fost inclusă și prevederea că, la traducerea într-o limbă modernă a numelor latinești, denumirile rezultate „trebuie să aibă o cît mai mare asemănare cu denumirile originale" (Candolle, 1868, p. 18). Măsura nu avea numai rolul de a susține stabilitatea terminologiei botanice, ci și de a cataliza popularizarea numelor savante de plante. Cataloagele primelor grădini botanice românești dovedesc, deci, că strategia de traducere legiferată la Congresul din 1867 era în uz încă din prima jumătate a secolului al XIX-lea, fiind valorificată de specialiști atît pentru a-i ajuta pe neofiți să înțeleagă ce caracteristici empirice ale plantelor se codifică în denumirile științifice, cît și pentru a înlesni crearea unor nume „de lucru”. Pentru neavizați, însoțirea unor denumiri de tipul Campanula barbata, Campanula alpina sau Campanula glomerata, cu adnotări precum clopoțăl bărbos, clopoțăl de munte sau clopoțăl adunat (Szabo, 2012, p. 214) poate părea artificială, opacă sau lipsită de sens. Pentru botanist, însă, adnotările sînt transparente și transmit fie că planta are niște perișori lungi și aspri ca firele de barbă sau că aceasta trăiește în regiunile montane, fie că florile sînt mici, dense și dispuse ca bobițele unui ciorchine. Fără veriga acestor mici exerciţii descriptive, astăzi nu am putea spune despre miros că e fetid sau fragrant, și nici n-am putea vorbi despre plante aromatice dacă adjectivele neologice respective nu s-ar fi acomodat în limba română după ce au fost mai întîi preluate și prelucrate pe filieră cultă.

În biblioteca naturii, cu cît o denumire savantă e mai veche, cu atît mai amplă e spirala evoluției sale (cf. Chirilă, 2019). De pildă, pentru plantele cunoscute la români prin denumiri populare cum ar fi gălbenele sau piciorul-cocoșului, lucrările de botanică sistematică înregistrează genul Ranunculus, nume generic ce putea fi preluat de Linné de la înaintaşi precum Christian Mentzel sau Gaspard Bauhin (Gledhill, 2008, p. 5). Denumirea savantă are ca sursă lexicală lat. ranunculus, termen adoptat de Plinius cel Bătrîn (23-79 d.Hr.) pentru a reda grecescul batrachion ('broscuță), folosit de Teofrast (ca. 340-287/6 î.Hr.) pentru a face referire la o plantă acvatică (cf. Stearn, 2013, p. 252). În Lexiconul de la Buda (1825), primul dicționar al limbii române cu suport linnean, menționarea genului Ranunculus figurează în cinci definiții ${ }^{14}$ :

\footnotetext{
${ }^{14} \mathrm{Am}$ valorificat ediția electronică realizată de un colectiv de cercetare coordonat de Maria Aldea [online].
} 
a) boglari: o floare, altmintre ră(n)unchiu: ranunculus Linn.: boglárvirág : der Ranunkel oder Hahnenfuß;

b) calce-mică: scînteuță-galcină: ranunculus ficaria, chelidonium minus Linn.: ara[n] nyal versengö: das kleine Schölkraut, Scharbockskraut, Feigwarzenkraut;

c) floare-broştească: o plantă: ranunculus acris Linn.: réti békavirág: der scharfe, brennende Hahnenfuß, die schmalzblume;

d) ranunchiu: o floare: ranunculus: boglárvirág, der Ranunkel, Hahnenfuß;

e) scînteuță: galbină: ranunculus ficaria vel chelidonium minus Linn.: aranny[a]l versengő: das kleine Schellkraut, Scharbockskraut, Feigwarzenkraut;

Pe de o parte, astfel de înregistrări lexicale ne permit să observăm că unele denumiri populare sînt împrumutate din alte limbi (rom. boglari - magh. Boglárvirág) ori indică formarea prin calchiere (rom. piciorul-cocoşului - germ. Hahnenfuß). Pe de altă parte, putem urmări cum s-a popularizat denumirea ştiințifică: germ. Ranunkel, rom. ranunchi și cum a fost aceasta „tradusă” în beneficiul posterităţii de primii farmaciști și medici care au adoptat sistemul stabilit de Linné: lat. ranunculus acris - rom. floare broştească $\breve{a}^{15}$. În sfîrșit, dicționarul reflectă și faptul că popularizarea denumirii culte a presupus intrarea în concurență cu forme lingvistice asemănătoare: ranunchi - rărunchi ('rinichi'), iar etimologia populară favorizată de omonimia rărunchi ('rinichi', 'măruntaie') - rărunchi (plantă) a fost ocazional dublată și de o derivare sinonimică: rînzişoară (Ranunculus sceleratus L.; Panțu, 1906, p. 232). Așadar, tălmăcirea codificărilor botanice pentru a le îngădui și neștiutorilor de latină să descopere ce taine ascund denumirile savante ale plantelor a contribuit decisiv la răspîndirea metaforelor deliberate create de oamenii de știință. La începutul secolului al XX-lea, traducerea denumirilor botanice erudite era privită de specialiști nu ca o practică excentrică și nefirească, după cum aprecia Simeon Mangiuca, ci ca mecanism de îmbogățire terminologică a discursului știinţific: „Toate națiunile mai înaintate în cultură şi-au stabilit nomenclatura botanică, dîndu-le plantelor nume şi în diferitele limbi naţionale pe lîngă numele ştiinţific. Aşa va trebui să facem şi noi, cînd învăţații români se vor gîndi şi la vulgarizarea ştiinței şi cînd se va ivi lipsa unei chei pentru determinarea plantelor, care e cel mai elementar şi necesar mijloc de-a răspîndi dragostea pentru flori şi pentru natură. Multe plante ce cresc pe pămîntul românesc îşi au deja numele popular. Celealalte trebuesc botezate cu numiri artificiale, dar neaoşe româneşti, ce corăspund spiritului limbii şi-şi găsesc analogia în numirile deja existente" (Borza, 1910, p. 376).

\section{Observații finale}

Analiza succintă a clasificării și nomenclaturii stabilitate de Linné în raport cu metafore ale scrisului cum ar fi CARTEA și BIBLIOTECA ne permite să semnalăm că spiritul cărturăresc al Iluminismului a prețuit foarte mult tradiția intelectuală a scrisului, care a devenit și mai bogată începînd cu secolul al XV-lea, odată cu apariția și dezvoltarea tiparului. După cum notează Umberto Eco (2016, p. 327-350), la întîlnirea dintre secolele al XVII-lea și al XVIII-lea, pe măsură ce ENCICLOPEDIA a devenit emblema simbolică a organizării cunoașterii, matricele metaforice tradiționale ale scrisului au fost reconfigurate pentru a pune în valoare valențe noi. În această privință, învățaţi precum Carl von Linné au redefinit studiul naturii prin raportare la organizarea informațională a unei biblioteci. Conform acestei viziuni, biblioteca naturii nu este altceva decît un labirint care așteaptă să fie explorat sistematic. Opera lui Aristotel a oferit firul călăuzitor prin labirintul lumii naturale, iar metafora marelui lanț al ființei a avut rolul de a întruchipa ordinea și armonia ce caracterizează arhitectura naturii pe care divinitatea a creat-o. Deși semințele teoriei evoluționiste care va înflori în operele unor mari naturaliști precum Alexander von Humboldt, Jean-Baptiste de Lamarck și Charles Darwin nu fuseseră încă plantate pe teren științific, metoda linneană a făcut posibilă descrierea rațională, precisă și bine organizată a realităţilor din lumea naturală.

\footnotetext{
${ }^{15}$ Dicționarele de etnobotanică (Panțu, 1906) indică și urmările denominative ale deciziei de a traduce în limba română denumirea științifică: broschiță (p. 27).
} 
Din unghi semiotic, implicaţiile metodei naturale pe care a stabilit-o Linné depășesc cadrul taxonomic și nomenclatural al biologiei întrucît pun în lumină configurația arborescentă a unui model de categorizare care a presupus corelarea unei scheme taxonomice potente $\mathrm{cu}$ un cadru nomenclatural ingenios construit. Altfel spus, naturalistul suedez a reunit tradiția și modernitatea într-un proiect care a deschis calea către adoptarea internațională a unei metode simple, coerente și eficiente de a stabili identitatea oricărui specimen în peisajul mai larg al vieții. Așadar, denumirile binare latinești stabilesc coordonatele de sistem ale unor metafore deliberare a căror traducere sau împrumutare în diverse limbi moderne a consolidat stabilitatea și circulația internațională a terminologiei biologice savante. Totodată, acest proces a îmbogățit vocabularele populare cu descendenți ai unor creații lingvistice dezvoltate în limbajul științific. În biblioteca naturii fiecare lucru are locul său.

\section{Bibliografie}

Aldea, M. (2011). Cîteva observații asupra definiției în „Lexiconul de la Buda” (1825), în „The Proceedings of the European Integration - Between Tradition and Modernity Congress", 4, p. 572-582.

Archibald, D.J. (2004). Aristotle's Ladder and Darwin's Tree. The evolution of Visual Metaphors for Biological Order, Columbia University Press, New York.

Bădeliță, C.-G. (2019). Mitul labirintului în proza italiană a secolului al XX-lea. Modelul greco-latin și valorificarea lui, Editura Universității „Alexandru Ioan Cuza”, Iași.

Blunt, W. (2001). Linneus. The Compleat Naturalist, with an introduction by William T. Stearn, Princeton University Press, Princeton / Oxford.

Bogdan, N.A. (1919). Societatea Medico-Naturalistă și Muzeul Istorico-Natural din Iaşi. 1830-1919. Documente, scripte și amintiri, Tipografia Națională, Iași.

Borza, Al. (1910). Nume populare de plante, în „Transilvania. Revista Asociațiunii pentru literatura română și cultura poporului român”, (5), sept.-oct., p. 376-377.

Borza, Al. (1921). Prima istorie naturală românească. Istoria naturei sau a firei de Gh. Șincai, în „Transilvania”, 52 (9-12), oct.dec., p. 825-836.

Borza, Al. (1929). Primul dicționar de științe naturale românesc. „Vocabularium pertinens ad tria Regna Nature” de Gh. Şincai, în „Dacoromanica. Buletinul «Muzeului Limbei Române»”, 5, 1927-1928, p. 553-562.

Brîndză, D. (1879-1883). Prodromul florei române sau enumerațiunea plantelor pînă astăzi cunoscute în Moldova și Valachia, Tipografia Academiei Române, Bucuresci, p. XI-LXXXIV.

Brîndză, D. (1880). Despre vegetațiunea României și exploratorii ei, cu date asupra climei și regiunilor botanice, discurs de recepție în Academia Română, Tipografia Academiei Române, București.

Cain, A.J. (1958). Logic and memory in Linnaus's system of taxonomy, în „Proceedings of the Linnean Society of London”, 169, p. 144-163, Crossref.

Candolle, A. (1868). Laws of Botanical Nomenclature adopted by the International Botanical Congress held at Paris in August 1867, L. Reeve \& Co., London.

Carruthers, M. (2008). The Book of Memory. A Study of Memory in Medieval Culture, second edition, Cambridge University Press.

Cassirer, E. (2008), Filosofia formelor simbolice, vol. I. Limbajul, traducere din limba germană de Adriana Cînța, Editura Paralela 45, Pitești.

Chirilă, A. (2019). La capătul îndepărtat al diacroniei: spirala evolutivă a apariției limbajului. O teorie, în „Diacronia”, 10, 7 nov., art. A141, Crossref.

Chivu, Gh. (2013). Nume de plante în texte vechi românești, în Oliviu Felecan (ed.), Numele și numirea. Actele Conferinței Internaționale de Onomastică, ediția a doua, Onomastica din spațiul public actual, Editura Mega, Editura Argonaut, ClujNapoca, p. 1000-1015.

Chivu, Gh. (2014). Prima listă de plante și începuturile terminologiei botanice românești, în Oana Uță Bărbulescu, Gheorghe Chivu (eds), Ion Coteanu - in memoriam, Editura Universității din București, p. 95-100.

Coteanu, I. (1942). Prima listă a numelor românești de plante, București.

Crease, R.P. (2006). The book of nature, în „Physics World”, 19 (12), Crossref.

Eco, U. (2016). Scrieri despre gîndirea medievală, Polirom, Iași.

Fĕtu, A. (1871). Enumerațiunea specieloru de plante cultivate în grădina botanică din Iași pêně în annulu 1870, Noua Typografiă a Laboratoriloru Români, Bucureci.

Fĕtu, A. (1873). Despre încercările făcutepentru dezvoltarea științtelor naturale în România, discurs de recepție, Analile Societăței Academice Române, seria I, tom V, seria II, Imprimeria Statului, București, p. 1-24, anexe, p. 125-159.

Florian, M. (1997). „Introducere la Categorii”, în Aristotel, Organon, vol. I, Editura Iri, Bucureşti. 
Gafton, Al. \& Gafton, E. (2015). Puterea imaginii, Dominația conceptului, Forța cuvîntului, în „The Proceedings of the International Conference Globalization, Intercultural Dialogue and National Identity. Section: Language and Discourse”, 2 , p. 11-32.

Gibbs, R.W. (2011). Are "deliberate” metaphors really deliberate?: A question of human consciousness and action, în „Metaphor and the Social World", 1 (1), p. 26-52, Crossref.

Gledhill, D. (2008). The Names of Plants, ediția a patra, Cambridge University Press, Crossref.

Harrison, P. 2004. "Priests of the Most High God, with respect to the Book of Nature". The Vocational Identity of the Early Modern Naturalist, în Angus J. Menuge (ed.), Reading God's World. The Scientific Vocation, Concordia Publishing House, Saint Louis, p. 59-84.

Heller, J.L. (1983). Studies in Linnean Method and Nomenclature, Peter Lang, Frankfurt am Main / Bern / New York.

Hofman, U. (1866). Catalogulu plantelor grădinei botanice a școalei de medicină din Bucuresci, Imprimeria Statului, Bucuresci.

Jeanrenaud, M. (2014). Europa secolului al XVIII-lea: traduceri și traducători, în Eugenia Dima, Andrei Corbea-Hoișie (eds), Impulsul Iluminismului în traduceri românești din secolul al XVIII-lea, Editura Universității „Alexandru Ioan Cuza”, Iaşi.

Laurian, A. T. \& Massim, J. C. (1871). Dictionariulu limbei române, Noua Typographia a Laboratoriloru Români, Bucuresci.

Linnæus, C. (2005). Philosophia Botanica, traducere de Stephen Freer, Oxford University Press.

Lovejoy, A.O. (2001). The Great Chain of Being, Harvard University Press, Cambridge, Massachusetts / London, England.

Mangiuca, S. (1874). De însemnătatea botanicei românesci, în „Familia”, 10 (43), 3-15 nov., p. 511-513.

Panțu, Z. (1906). Plantele cunoscute de poporul român, Institutul de Arte Grafice și Editură „Minerva”, București.

Pavel, E. (coord.) (2018). Școala Ardeleană, Academia Română, Fundația Națională pentru Știință și Artă, Muzeul Național al Literaturii Române, București, 4 volume.

Rieger, D. (2000). «Des «livres sacrés». Fiction et idée de la bibliothèque au Moyen Îge», în „Cahiers de recherches médiévales”, 7, Crossref.

Rosch, E. (1999). Reclaiming concepts, în „Journal of Consciousness Studies”, 6 (11-12), p. 61-77.

Serafini, A. (1993). The Epic History of Biology, Perseus Publishing.

Soare, L. (2010). Școala Ardeleană. Aspects of Biology Terminology, în „Analele Universității din Craiova, seria Științe filologice. Lingvistică", 32 (1-2), p. 364-370.

Stafleu, F.A. (1971). Linneus and the Linneans. A. Ooshoek's Uitgeversmaatschappij N. V., Utrecht.

Stearn, W.T. (1959). The Background of Linneus's Contributions to the Nomenclature and Methods of Systematic Biology, în „Systematic Biology", 8 (1), p. 4-22, Crossref.

Stearn, W.T. (2013). Botanical Latin, David \& Charles, Timber Press.

Steen, G.J. (2011). When is metaphor deliberate?, in N-L. Johannesson, C. Alm-Arvius, \& D. C. Minugh (eds), Selected Papers from the Stockholm 2008 Metaphor Festival (Stockholm Studies in English), University of Stockholm, Stockholm, p. 43-63, [online].

Szabo, J. (2012). Flora moldavica (1841-1842), ediție de Milian Gurău, Alma Mater, Bacău.

Tanzella-Nitti, G. (2005). The Two Books prior to the Scientific Revolution, în „Perspectives on Science and Christian Faith”, 57 (3), p. 235-248, [online]. 
Anexa A. Clasificarea bibliografică propusă de Carl von Linné: Bibliotheca Botanica (1735)

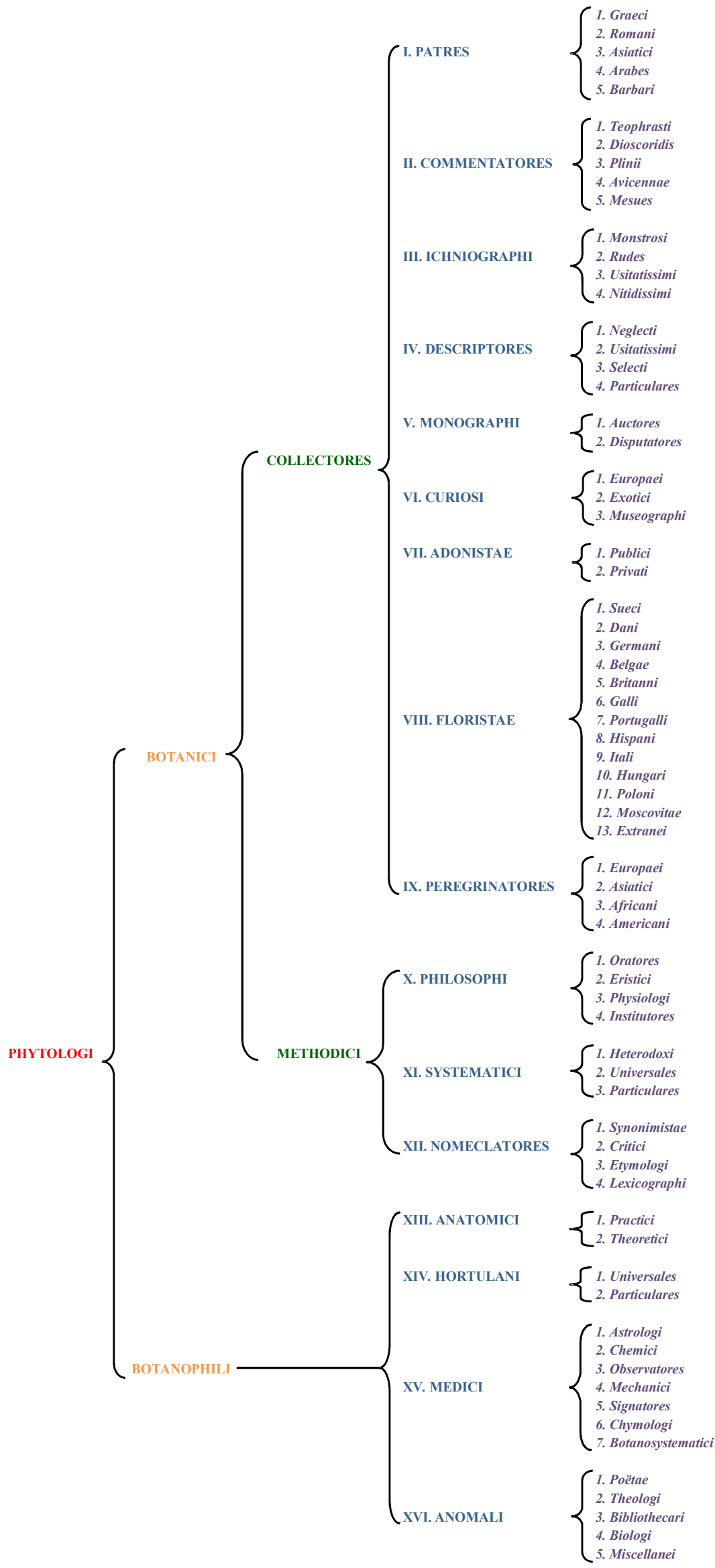

